\title{
GAMBARAN PENGETAHUAN, SIKAP, DAN PERILAKU MEROKOK PADA PASIEN HIPERTENSI DI RUMAH SAKIT UMUM DAERAH PALEMBANG BARI
}

\author{
Joko Tri Wahyudi \\ Program Studi IImu Keperawatan IKesT Muhammadiyah Palembang, \\ Korespondensi Email : joko.mkep@gmail.com
}

\begin{abstract}
ABSTRAK
Pendahuluan : Hipertensi merupakan awal dari munculnya penyakit - penyakit katastropik. Hampir setiap tahun sebanyak delapan miliyar orang di dunia meninggal karena hipertensi dan hampir 1,5 juta orang setiap tahunnya di kawasan Asia Timur-Selatan meninggal karena hipertensi. Salah satu faktor yang beresiko memicu seseorang terserang penyakit hipertensi adalah merokok. Merokok sudah dikenal masyarakat sebagai salah satu penyebab kematian yang cukup besar di dunia. Berbagai penelitian telah membuktikan ada banyak bahaya merokok bagi kesehatan. Diantaranya yaitu asma, infeksi paru-paru, kanker mulut, kanker tenggorokan, kanker paru-paru, serangan jantung, stroke, demensia (penurunan kemampuan fungsi otak), disfungsi ereksi (impoten), dan sebagainya. Penderita hipertensi sudah mengetahui bahwa merokok akan memperberat hipertensinya dan menjadi hambatan (barriers) bagi kesembuhan, namun penderita hipertensi masih tetap menjalani perilaku merokoknya. Oleh karena itu peneliti berkeinginan mencari alasan mengapa pasien dengan penyakit hipertensi masih tetap merokok. Penelitian ini dilakukan untuk mengetahui seperti apakah gambaran pengetahuan, sikap dan perilaku merokok pada pasien Hipertensi di Rumah Sakit Umum Daerah Palembang Bari. Metode : Desain penelitian yang digunakan adalah penelitian kuantitatif dengan metode purposive sampling dengan jumlah sampel 45 responden. Hasil : Hasil penelitian menyatakan bahwa dari 45 responden yang diteliti diperoleh Pengetahuan Baik (48,9\%), sebanyak (91,1\%) memiliki Sikap Positif dan sebanyak $(8,9 \%)$ dengan Tindakan Baik. Simpulan : Pengetahuan pasien hipertensi tentang merokok masuk dalam kategori baik, sikap pasien hipertensi tentang merokok masuk kategori positif dan tindakan merokok pasien hipertensi masuk kategori cukup baik.
\end{abstract}

Kata Kunci : Hipertensi, Perilaku Merokok

\section{Knowledge, Attitude and Smoking Behavior of Hypertension Patients at BARI Hospital, Palembang}

\begin{abstract}
Introduction: Hypertension is the beginning of the catastrophic diseases. Hypertension kills almost 8 billions people each year in the world and almost 1,5 billions people each year in South-East Asia region. About a third of adult males in South-East Asia Region are having hypertension. One of risk factors that trigger hypertension is smoking. Smoking can cause Hypertension due to nicotine can stimulates the release of catecholamine which causes irritability, myocardial, the increase of heart beat and also causes vasoconstriction that lead to the increase of blood pressure. The purpose of this study is to identify the description of Smoking Behavior of Hypertentive Patients at Rumah Sakit Umum Daerah Palembang BARI. Methods : Research design for this study was a quantitative research using descriptive analysis which aimed to describe the study object through data and the collected samples were 45 respondents. Result : From the results of the study showed that from 45 respondents there were (13,1\%) with Less Knowledge, (37,8\%) with Adequate Knowledge, and $(48,9 \%)$ with Good Knowledge. There were (8,9\%) with Negative Behavior, and $(9,1 \%)$ with Positive Attitude. Then (31,1\%) with Less Good Behavior, $(60,0 \%)$ with Adequate Action, and (8,9\%) with Good Action. Conclusion: Knowledge of hypertentive patients about
\end{abstract}


smoking is categorized into good, patient's behavior about hypertension is categorized into positive and smoking action of hypertension patients is categorized into adequately good.

Keywords : Hypertension, Smoking Behavior

\section{PENDAHULUAN}

Hipertensi adalah salah satu penyebab utama kematian dini diseluruh dunia. Hipertensi disebut juga menjadi salah satu penyakit yang sering disebut sebagai "pembunuh diam-diam" karena penyakit ini tidak menyebabkan gejala jangka panjang. Biasanya, penderita tidak mengetahui kalau dirinya mengidap hipertensi dan baru diketahui setelah terjadi komplikasi. Jika tidak terdeteksi dini dan terobati tepat waktu, hipertensi dapat mengakibatkan komplikasi serius seperti PJK, gagan jantung, stroke, kebutaan, diabetes, dan banyak penyakit berbahaya lainnya. Hipertensi merupakan faktor risiko untuk berbagai penyakit kardiovaskular dan stroke (Benjamin dkk, 2017).

Hipertensi merupakan awal dari munculnya penyakit - penyakit katastropik. Penyakit katastropik adalah penyakit yang memerlukan biaya tinggi, komplikasi dan membahayakan jiwa. Menurut Indonesian Society of Hypertension (InaSH), data mencatat tren jumlah penyakit hipertensi masih dan terus meningkat, bahkan laporan BPJS pada akhir 2017 menunjukkan berbagai penyakit yang berkaitan dengan hipertensi langsung seperti gagal ginjal, stroke, dan penyakit jantung, merupakan penyakit katastropik yang menyita biaya negara dalam jumlah sangat besar.

Hampir semua orang dapat mengalami tekanan darah tinggi. World Health Organization (WHO) menyebut angkanya saat ini terus meningkat secara global. Peningkatan orang-orang dewasa di seluruh dunia yang akan mengidap hipertensi diprediksi melonjak hingga 29 persen pada tahun 2025. Di tahun 2020 sekitar 1,56 miliar orang dewasa akan hidup dengan hipertensi. Hipertensi membunuh hampir 8 miliyar orang setiap tahun di dunia dan hampir 1,5 juta orang setiap tahunnya di kawasan Asia TimurSelatan. Sekitar sepertiga dari orang dewasa di Asia Timur-Selatan menderita hipertensi (World Health Organization, 2015).

Peningkatan kasus hipertensi juga terjadi di Indonesia. Data Riset Kesehatan Dasar (Riskesdas) milik Kemenkes RI tahun 2013 menunjukkan bahwa 25,8 persen penduduk Indonesia mengidap hipertensi. Sementara itu, data Survei Indikator Kesehatan Nasional (Sirkesnas) tahun 2016 menunjukkan peningkatan prevalensi hipertensi pada penduduk usia 18 tahun ke atas sebesar 32,4 persen. Lalu data Riset Kesehatan Dasar (Riskesdas) milik Kemenkes RI tahun 2018 menunjukkan bahwa 34,1 persen penduduk Indonesia mengidap hipertensi.

$$
\text { Provinsi Sumatera Selatan }
$$

khususnya kota Palembang merupakan salah satu wilayah Indonesia yang mempunyai prevalensi hipertensi yang tinggi dibandingkan dengan wilayahwilayah lain. Berdasarkan data dari Dinkes Provinsi Sumatera Selatan, jumlah penderita hipertensi pada tahun 2007 sebesar 32.902 orang dan pada tahun 2008 berjumlah 32.270 orang. Penyakit hipertensi masuk ke dalam "10 penyakit terbesar januari 2017" di kota Palembang dan menempati peringkat kedua. (Dinkes Sumatera Selatan, 2017)

Berdasarkan data yang didapatkan langsung di Rumah Sakit Umum Daerah Palembang BARI pada tanggal 25-27 februari 2019, penderita hipertensi yang melakukan kunjungan di poliklinik penyakit dalam pada tahun 2018 berjumlah 591 orang.

Faktor risiko yang memicu terjadinya hipertensi dibagi menjadi dua yaitu faktor yang tidak dapat dikontrol dan faktor yang dapat dikontrol. Faktor yang tidak dapat dikontrol meliputi usia, jenis kelamin, dan keturunan (genetik). Faktor yang dapat dikontrol meliputi kegemukan (obesitas), dislipidemia (kadar lemak dalam aliran darah tidak normal), stress, konsumsi alkohol berlebih, konsumsi garam berlebih, 
aktivitas fisik, diet yang tidak seimbang dan merokok (Sudarmoko, 2015).

Merokok merupakan suatu masalah di dalam masyarakat yang dapat menimbulkan banyak kerugian baik dari segi sosial ekonomi maupun kesehatan bahkan kematian (Kemenkes RI, 2011). Perilaku merokok merugikan kesehatan karena dapat mengakibatkan banyak penyakit, diantaranya penyakit pada sistem kardiovaskular, penyakit pada sistem respirasi, kanker, dan masalah kesehatan yang lainnya seperti impotensi, kehamilan premature, bayi baru lahir rendah (BBLR) dan lain - lain (Centers for Disease Control and Prevention, 2012).

Berdasarkan data Riset Kesehatan Dasar (Riskesdas) tahun 2018, proporsi penduduk umur >15 tahun yang merokok dan mengunyah tembakau cenderung meningkat, berdasarkan Riset Kesehatan Dasar tahun 2007 sebesar 34,2\%, Riset Kesehatan Dasar tahun 2010 sebesar $34,3 \%$, Riset Kesehatan Dasar tahun 2013 sebesar 36,3\%, Survei Indikator Kesehatan Nasional (Sirkesnas) tahun 2016 sebesar $32.8 \%$, dan Riset Kesehatan Dasar tahun 2018 menjadi $33,8 \%$.

Tiap rokok mengandung kurang lebih 4000 bahan kimia, dan hampir 200 diantaranya beracun dan 43 jenis yang dapat menyebabkan kanker bagi tubuh (Khoirudin, 2006). Merokok dapat menyebabkan hipertensi, kandungan nikotin dalam rokok dapat merangsang pelepasan katekolamin. Peningkatan katekolamin ini mengakibatkan iritabilitas miokardial, peningkatan denyut jantung, serta menyebabkan vasokontriksi yang kemudian meningkatkan tekanan darah (Muhammad Ardiansyah, 2012).

Dari hasil studi pendahuluan yang dilakukan dengan cara wawancara langsung kepada Tn. L berusia 48 tahun yang mengidap hipertensi pada 27 februari 2019 di Rumah Sakit Umum Daerah Palembang BARI, beliau mengatakan ia masih merokok sampai sekarang dan alasan beliau masih merokok padahal sudah tahu memiliki penyakit hipertensi adalah untuk melepas stress karena bekerja, beliau juga mengatakan dengan merokok perasaan beliau bisa menjadi lebih tenang dan santai.

Dari penelitian sebelumnya yang dilakukan oleh Kesuma Indah Sriani, Rudi Fakhriadi, Dian Rosadi tahun 2016 yang berjudul Hubungan Antara Perilaku Merokok Dan Kebiasaan Olahraga Dengan Kejadian Hipertensi Pada Laki-laki Usia 18 - 44 Tahun Di Wilayah Kerja Puskesmas Sungai Besar Kecamatan Banjarbaru Selatan didapatkan hasil bahwa hipertensi pada orang yang merokok masih tinggi yaitu sebesar $81,35 \%$.

Penelitian yang dilakukan oleh indar kurniawan tahun 2017 yang berjudul Hubungan Perilaku Merokok dengan Kejadian Hipertensi di Puskesmas Pajangan Bantul, sebagian responden menderita hipertensi grade 1, dimana hipertensi grade 1 sering terjadi pada lakilaki dengan usia diatas dari 40 tahun lebih cenderung menderita hipertensi. Perilaku merokok dalam penelitian ini dinilai dari frekuensi merokok perhari, jumlah rokok yang dihisap perhari, dan ada tidaknya ketergantungan terhadap tembakau. Jumlah konsumsi rokok perhari dapat digunakan sebagai indicator tingkat merokok seseorang, dalam penelitian ini konsumsi rokok dikategorikan menjadi perokok ringan, perokok sedang dan perokok berat.

Berdasarkan jabaran data-data di atas membuat peneliti sangat tertarik dan ingin mengetahui bagaimana gambaran penegtahuan, sikap dan perilaku merokok pada pasien hipertensi dipalembang khususnya di Rumah Sakit Umum Daerah Palembang BARI.

\section{BAHAN DAN METODE}

Penelitian ini merupakan jenis penelitian kuantitatif. Desain penelitian yang digunakan adalah deskriptif analisis yang berfungsi untuk mendeskripsikan atau memberi gambaran terhadap objek yang diteliti melalui data atau sampel yang telah terkumpul. Penelitian ini dilakukan di Rumah Sakit Umum Daerah Palembang Bari. Penelitian ini dilaksanakan pada tanggal 29 April sampai 11 Mei 2019. Populasi dalam penelitian ini adalah pasien yang menderita hipertensi di poliklinik 
penyakit dalam Rumah Sakit Umum Daerah Palembang BARI. Tehnik sampling yang digunakan dalam penelitian ini adalah Purposive sampling.

Penelitian ini di pilih berdasarkan Kriteria Inklusi, yaitu Pasien yang menderita hipertensi di poliklinik penyakit dalam RSUD Palembang BARI. Mempunyai kebiasaan merokok, pernah merokok atau mempunyai riwayat merokok dan bersedia menjadi responden dan mengisi kuesioner penelitian secara lengkap. Variabel yang digunakan dengan analisis univariat. Pada penelitian ini adalah Karakteristik Responden dan karakteristik Perilaku Merokok pada pasien hipertensi di Rumah Sakit Umum Daerah Palembang BARI. Pengelolaan dan analisa data dengan SPSS. Analisa digunakan untuk mendeskripsikan masing-masing varibel.

\section{HASIL}

\section{Karakteristik Responden}

Berdasarkan hasil penelitian terhadap 45 orang pasien dengan hipertensi di Rumah Sakit Umum Daerah Palembang BARI pada bulan April 2019, diperoleh karakteristik pasien sebagai berikut.

\section{Tabel 1 \\ Karakteristik Responden Usia, Jenis kelamin, dan Pendidikan.}

\begin{tabular}{lc}
\hline \multicolumn{1}{c}{ Karakteristik } & $\mathbf{n}(\%)$ \\
\hline Usia (Tahun) (Median \pm SD) & $61.00 \pm$ \\
Jenis kelamin & 12.414 \\
$\quad$ Laki - laki & \\
$\quad$ Perempuan & $97.8 \%$ \\
Pendidikan & $2.2 \%$ \\
SD & \\
SMP & $44.4 \%$ \\
SMA & $13.3 \%$ \\
Perguruan Tinggi & $35.6 \%$ \\
\hline
\end{tabular}

Rata - rata umur pasien yang menderita hipertensi adalah pada usia 58 tahun Hampir setengahnya $(31,1 \%)$ atau sebanyak 14 responden yang menderita hipertensi masuk di kategori usia manula dan $(28,9 \%)$ atau sebanyak 13 responden lainnya masuk di kategori lansia akhir di RSUD Palembang Bari. Pada laki-laki hipertensi terjadi pada usia > 55 tahun, sedangkan pada wanita hipertensi terjadi pada usia > 65 tahun dan risikonya meningkat setelah mengalami masa menopause (Kotchen., 2012). Usia responden terendah 31 tahun dan tertinggi 80 tahun.

Berdasarkan penelitian dan teori yang ada, peneliti berasumsi bahwa semakin bertambahnya usia maka tekanan darah akan cenderung meningkat pula dan resiko untuk menderita penyakit hipertensi akan semakin tinggi juga.

Hampir seluruh pasien yang menderita hipertensi $(97,8 \%)$ berjenis kelamin laki - laki. Kebanyakan responden dalam penelitian ini berjenis kelamin laki laki karena laki - laki adalah mayoritas perokok di Indonesia, sehingga jarang terdapat wanita yang merokok. Umumnya laki - laki lebih mudah terserang hipertensi dibandingkan dengan wanita. Hal ini dikarenakan laki - laki lebih banyak mempunyai faktor risiko yang mempengaruhi terjadinya hipertensi seperti merokok dan makan tidak terkontrol. Biasanya wanita akan mengalami peningkatan hipertensi setelah masa menopause (Suiraoka, 2012).

Berdasarkan penelitian dan teori yang ada, peneliti berasumsi hampir seluruh responden berjenis kelamin laki laki karena memang jarang ditemukan wanita yang merokok dan mayoritas perokok di Indonesia adalah laki - laki.

Pendidikan responden hampir setengahnya $(44,4 \%) \quad$ mempunyai pendidikan terakhir SD dan sebagian kecil $(6,7 \%)$ lainnya mempunyai pendidikan terakhir Perguruan Tinggi. Tingkat pendidikan secara tidak langsung mempengaruhi tekanan darah. Tingkat pendidikan berpengaruh terhadap gaya hidup yaitu kebiasaan merokok, kebiasaan minum alkohol, dan lain - lain. Hasil Riskesdas tahun 2013 dalam Badan penelitian dan Pengembangan Kesehatan (2013) menyatakan bahwa penyakit hipertensi cenderung tinggi pada pendidikan rendah dan menurun sesuai 
dengan peningkatan pendidikan. Tingginya resiko terkena hipertensi pada pendidikan yang rendah, kemungkinan disebabkan karena kurangnya pengetahuan pada seseorang yang berpendidikan rendah terhadap kesehatan dan sulit atau lambat menerima informasi (penyuluhan) yang diberikan oleh petugas sehingga berdampak pada perilaku/pola hidup sehat (Anggara dan Prayitno, 2013).

Peneliti berasumsi dalam penelitian dan teori yang ada bahwa pendidikan dapat mempengaruhi perilaku seseorang, karena semakin tinggi pendidikan seseorang maka semakin mudah seseorang menerima informasi, sehingga pengetahuan nya menjadi lebih baik. Pengetahuan yang baik akan mempengaruhi perilaku seseorang menjadi lebih baik. Karakteristik responden secara rinci juga di tampilkan pada tabel 1.

\section{Tabel 2}

Rata-rata Lama merokok dan Jumlah rokok yang dihisap perhari pasien hipertensi.

\section{Karak- \\ teristik N Mean Median Min Max SD}

\begin{tabular}{lllllll}
\hline $\begin{array}{l}\text { Lama } \\
\text { merokok }\end{array}$ & 45 & 17.27 & 18.00 & 6 & 28 & 7.475 \\
$\begin{array}{l}\text { Jumlah } \\
\begin{array}{l}\text { rokok yg } \\
\text { dihisap/ } \\
\text { hr }\end{array}\end{array}$ & 45 & 9.80 & 8.00 & 5 & 24 & 5.003 \\
\hline
\end{tabular}

Hasil penelitian menunjukkan bahwa rata - rata lama merokok di dapatkan skor mean 17,27, median 18,00 dan standar deviasi 7,475 dengan nilai maximum 28 , minimum 6 dengan 95\% tingkat kepercayaan antara 15.02-19.51. Salah satu zat yang terdapat dalam rokok adalah nikotin. Zat ini mempunyai efek adiksi, sehingga orang - orang yang merokok menjadi kecanduan dan sulit untuk berhenti merokok jika sudah menjadi kebiasaan. Hal inilah yang membuat sebagian orang merokok sampai puluhan tahun lamanya (Fidrianny, 2004). Merokok juga dapat meningkatkan tekanan darah menjadi tinggi. Kebiasaan merokok dapat meningkatkan risiko diabetes, serangan jantung, dan stroke. Karena itu, kebiasaan merokok yang terus dilanjutkan ketika memiliki tekanan darah tinggi, merupakan kombinasi yang sangat berbahaya yang akan memicu penyakit- penyakit yang berkaitan dengan jantung dan darah (Irianto, 2015).

Penelitian rata - rata jumlah rokok yang dihisap perhari di dapatkan skor mean 9,80, median 8,00 dan standar deviasi 5,003 dengan nilai maximum 24, minimum 5 dengan 95\% tingkat kepercayaan antara 8.30-11.30. Jumlah rokok yang dihisap perhari dapat menentukan seseorang adalah perokok berat, sedang dan ringan. Menurut (Mu"tadin, 2002) perilaku merokok berdasarkan intensitas merokok membagi jumlah rokok yang dihisapnya setiap hari, yaitu: Perokok berat adalah perokok yang menghabiskan 21-30 batang rokok setiap hari dengan selang waktu merokok berkisar 6-30 menit setelah bangun tidur pagi hari, Perokok sedang adalah perokok yang mengkomsumsi rokok cukup yaitu 11-20 batang per hari dengan selang waktu 31-60 menit mulai bangun tidur, Perokok ringan adalah perokok yang mengkomsumsi rokok jarang yaitu sekitar 10 batang per hari dengan selang waktu 60 menit dari bangun tidur pagi.

Berdasarkan penelitian dan teori yang ada, peneliti berasumsi masing masing individu memiliki lama merokok yang berbeda - beda, ada yang paling singkat selama 6 tahun dan yang terlama 28 tahun. Kandungan nikotin dalam rokok dapat merangsang pelepasan katekolamin, peningkatan katekolamin ini mengakibatkan iritabilitas miokardial, peningkatan denyut jantung, serta menyebabkan vasokontriksi yang kemudian meningkatkan tekanan darah. Perokok yang menghisap 5 batang setiap hari memiliki risiko meningkatnya tekanan darah yang setara dengan perokok yang menghisap 24 batang rokok perhari. Merokok membawa dampak negative yang sangat besar bagi kesehatan, baik bagi perokok yang menghabiskan puluhan batang maupun perokok yang hanya menghisap satu batang setiap hari. Tidak ada perokok yang aman dari penyakit 
kardiovaskular. Perokok harus berhenti total apabila ingin terhindar dari penyakit kardiovaskular. Skor rata-rata lama merokok dan rata-rata jumlah rokok yang dihisap perhari pada pasien hipertensi secara rinci di tampilkan di tabel 2 .

\section{Analisis Univariat}

Berdasarkan penelitian dan teori yang ada, peneliti berasumsi bahwa sebagian besar pasien sudah memiliki tindakan yang cukup baik terhadap perilaku merokok, Meskipun pengetahuan dan sikap merokok responden sudah baik, namun masih ada saja sebagian kecil yang masih memiliki tindakan merokok yang kurang baik. Ini disebabkan karena efek yang ditimbulkan oleh rokok yang baru dirasakan setelah beberapa tahun, oleh karena itu ada perokok yang enggan berhenti merokok karena belum merasakan dampak nyata yang disebabkan oleh rokok. Skor rata-rata

Tabel 3

Rata-rata Perilaku merokok yang mencakup pengetahuan, sikap dan tindakan pasien hipertensi.

\begin{tabular}{ccccccc}
\hline $\begin{array}{c}\text { Perilaku } \\
\text { Merokok }\end{array}$ & N & Mean & Median & Min & Max & SD \\
\hline Pengetahuan & 45 & 13.31 & 13.00 & 7 & 17 & 2.945 \\
Sikap & 45 & 46.56 & 47.00 & 37 & 60 & 5.172 \\
Tindakan & 45 & 35.11 & 34.00 & 22 & 60 & 8.791 \\
\hline
\end{tabular}

Tabel 4

Rata-rata Perilaku merokok yang mencakup pengetahuan, sikap dan tindakan pasien hipertensi

\begin{tabular}{cc}
\hline Perilaku Merokok & $\mathbf{n ( \% )}$ \\
\hline Pengetahuan & \\
Baik & $48.9 \%$ \\
Cukup & $37.8 \%$ \\
Kurang & $13.3 \%$ \\
Sikap & \\
Positif & $91.1 \%$ \\
Negatif & $8.9 \%$ \\
Tindakan & \\
Baik & $8.9 \%$ \\
Cukup & $60.0 \%$ \\
Kurang & $31.1 \%$ \\
\hline
\end{tabular}

tindakan beserta kategorinya pada pasien hipertensi secara rinci juga di tampilkan di tabel 3 dan 4.

\section{PEMBAHASAN \\ Pengetahuan}

Berdasarkan hasil penelitian yang di lakukan di RSUD Palembang BARI menunjukkan bahwa hampir setengahnya atau sebanyak (48,9\%) pasien hipertensi mempunyai pengetahuan yang baik, (13,3\%) dengan Pengetahuan Kurang, dan $(37,8 \%)$ dengan Pengetahuan Cukup.

Mengkonsumsi rokok dalam jangka pendek maupun panjang dan dalam jumlah konsumsi yang tinggi akan mempengaruhi kondisi fisik seseorang. Karena jika seseorang mengkonsumsi rokok secara rutin maka gigi, kuku, dan jari tangan seseorang dapat berwarna kuning dan mempengaruhi rasa percaya diri, menggangu hubungan dengan orang lain, dan tidak tenang (Wismanto \& Sarwo, 2007). Hasil penelitian ini sejalan dengan penelitian yang dilakukan oleh Jatmika (2015) bahwa $46,67 \%$ penderita hipertensi di desa sidokarto kecamatan godean sleman yogyakarta memiliki pengetahuan cukup baik tentang bahaya merokok. Hal ini dapat disebabkan karena sebenarnya sudah banyak peringatan peringatan dan informasi tentang bahaya merokok, misalnya di bungkus rokok, di baliho - baliho di jalan, dan beberapa kawasan bebas rokok yang biasanya terdapat informasi tentang bahaya merokok.

Berdasarkan penelitian dan teori yang ada, peneliti berasumsi pengetahuan pada responden yang menderita hipertensi sudah baik, terutama pada dampak dan penyakit akibat kebiasaan merokok. Hal ini dapat disebabkan karena sebenarnya sudah banyak peringatan - peringatan dan informasi tentang bahaya merokok, misalnya di bungkus rokok, di baliho baliho di jalan, dan beberapa kawasan bebas rokok yang biasanya terdapat informasi tentang bahaya merokok. 
Skor rata rata pengetahuan beserta kategorinya pada pasien hipertensi secara rinci juga di tampilkan di tabel 4 dan 5.

\section{Sikap}

Berdasarkan hasil penelitian yang di lakukan di RSUD Palembang BARI menunjukkan bahwa hampir seluruhnya atau sebanyak (91,1\%) pasien hipertensi mempunyai sikap yang positif terhadap perilaku merokok lalu sebagian kecil (8,9\%) dengan Sikap Negatif,

Hasil penelitian juga menunjukkan bahwa dari 45 responden, sebesar $86 \%$ responden setuju bahwa peringatan yang ada pada kemasan rokok adalah benar. Kemudian 81\% responden setuju untuk tidak merokok di depan anak-anaknya, lalu sebanyak $84 \%$ responden juga setuju untuk tidak merokok di ruangan ber-AC. Sebanyak $79 \%$ responden setuju bahwa asap rokok berbahaya bagi orang disekitar perokok, dan sebanyak $78 \%$ responden setuju bahwa merokok adalah kebiasaan buruk. Sebanyak $84 \%$ responden setuju merokok dapat membuat seseorang kecanduan. Sebanyak $70 \%$ responden setuju bahwa iklan rokok harus dihentikan. Sebanyak $76 \%$ responden setuju bahwa peraturan kawasan tanpa rokok sebaiknya di adakan di tempat umum. Hasil penelitian ini tidak sejalan dengan penelitian yang dilakukan oleh Jatmika (2015) bahwa sebanyak 63,3\% penderita hipertensi di desa sidokarto kecamatan godean sleman yogyakarta memiliki sikap negatif.

Berdasarkan penelitian dan teori yang ada, peneliti berasumsi bahwa sikap responden terhadap suatu perilaku didasarkan atas keyakinan dan pengetahuan tentang akibat positif dan negative dari perilaku merokok. Hampir seluruh responden memiliki sikap yang positif terhadap perilaku merokok, hal ini dikarenakan pengetahuan responden sudah cukup baik sehingga menimbulkan sikap yang positif. Skor rata rata sikap beserta kategorinya pada pasien hipertensi secara rinci juga di tampilkan di tabel 4 dan 5 .

\section{Tindakan}

Berdasarkan hasil penelitian yang di lakukan di RSUD Palembang BARI menunjukkan bahwa sebagian besar $(60,0 \%)$ pasien hipertensi mempunyai tindakan yang cukup baik, (31,1\%) Hasil penelitian juga menunjukkan bahwa sebesar $84 \%$ responden tidak merokok dalam jumlah batang yang bertambah dari hari ke hari, lalu sebanyak $78 \%$ responden tidak merokok saat merasa cemas, gelisah, jenuh dan kesal. Sebanyak 48\% responden tidak merokok ketika mulut terasa asam. Sebanyak 66\% responden tidak merokok di tempat sepia tau tidak banyak orang. Dan sebanyak $54 \%$ responden tidak merokok pada saat ada teman yang mengajak untuk merokok. Hasil penelitian ini tidak sejalan dengan penelitian yang dilakukan oleh Jatmika (2015) bahwa sebanyak 66,67\% penderita hipertensi di desa sidokarto kecamatan godean sleman yogyakarta memiliki perilaku yang kurang baik.

Perilaku merokok adalah menghisap asap tembakau yang telah menjadi cerutu kemudian disulut api. Menurutnya ada dua tipe merokok. Pertama adalah menghisap rokok secara langsung yang disebut perokok aktif, dan yang kedua mereka yang secara tidak langsung menghisap rokok. Namun turut menghisap asap rokok disebut perokok pasif. Bermacam - macam perilaku yang dilakukan manusia dalam menanggapi stimulus yang diterimanya, salah satu bentuk perilaku manusia yang dapat diamati adalah perilaku merokok (Sukmana, 2008).

\section{SIMPULAN DAN SARAN Simpulan}

Berdasarkan hasil penelitian yang telah dilakukan tentang perilaku merokok di poliklinik penyakit dalam rumah sakit umum daerah palembang bari pada tanggal 29 April - 11 Mei 2019 dengan 
jumlah sample 45 responden didapatkan kesimpulan sebagai berikut:

a. Karakteristik Responden

1) Rata - rata responden berusia 58 tahun dan hampir setengahnya $(31,1 \%)$ masuk di kategori usia manula.

2) Hampir seluruh responden $(97,8 \%)$ berjenis kelamin laki - laki.

3) Hampir setengah responden $(44,4 \%)$ mempunyai pendidikan terakhir SD dan sebagian kecil lainnya $\quad(6,7 \%) \quad$ mempunyai pendidikan terakhir Perguruan Tinggi.

4) Rata - rata responden merokok selama 17 tahun.

5) Rata - rata responden menghisap rokok sebanyak 10 batang perhari.

b. Karakteristik Perilaku Merokok

1) Rata - rata pengetahuan responden mendapatkan skor 13 yang berarti mempunyai pengetahuan yang cukup baik dan hampir setengah responden $(48,9 \%)$ masuk kategori mempunyai pengetahuan yang baik tentang bahaya merokok.

2) Rata - rata sikap responden mendapatkan skor 47 yang berarti mempunyai sikap yang positif dan hampir seluruh responden $(91,1 \%)$ masuk kategori mempunyai sikap yang positif terhadap perilaku merokok.

3) Rata - rata tindakan responden mendapatkan skor 35 yang berarti mempunyai tindakan yang cukup baik dan sebagian besar responden $(60,0 \%)$ masuk kategori mempunyai tindakan yang cukup baik terhadap perilaku merokok.

\section{Saran}

Berdasarkan kesimpulan hasil penelitian ini, peneliti mengajukan saran saran sebagai berikut:

\section{Bagi Institusi Pendidikan}

Bagi institusi pendidikan khususnya Stikes Muhammadiyah Palembang supaya dapat menjadi referensi dan sumber pustaka serta dapat menambah bahan bacaan khususnya tentang ilmu keperawatan medikal bedah.

\section{Bagi Rumah Sakit}

Bagi rumah sakit agar dapat memberikan penyuluhan dan peringatan secara rutin tentang bahaya merokok serta memberikan motivasi akan pentingnya berhenti merokok.

\section{Bagi Peneliti Selanjutnya}

Bagi peneliti selanjutnya perlu mengidentifikasi lebih dalam dengan metode kualitatif tentang faktor - faktor yang bisa mempengaruhi perilaku merokok pada penderita hipertensi.

\section{KEPUSTAKAAN}

Ardiansyah, Muhammad. 2012. Medical Bedah Untuk Mahasiswa. Jogjakarta : DIVA Ekspres.

Badan Litbangkes Kemenkes RI, 2011. Laporan Akhir Riset Fasilitas Kesehatan tahun 2011, Jakarta.

Badan Penelitian dan Pengembangan Kesehatan Kementerian Kesehatan, 2013. Rliset Kesehatan Dasar, Jakarta.

Benjamin EJ, Blaha MJ, Chiuve SE, Cushman M, Das SR, Deo R, et al. Heart disease and stroke statistics2017 update: a report from the American Heart Association.Circulation.2017

Center for Disease Control and Prevention (CDC) 2012. Body Mass Index:Considerations for Practitioners. 1-4

Departemen Kesehatan Republik Indonedia (Depkes RI) 2016. Profil Keseheatan Indonesia Tahun 2016. Kementerian Kesehatan Republik Indonesia.Dinas Kesehatan Kabupaten Bantul. (2014). Profil Kesehatan Kabupaten Bantul Tahun 2014. BantuIDewanto, I. (2013). Dokter Gigi DalamSistem Jaminan Kesehatan Nasional.

Dinkes Kota Palembang. Profil Kesehatan Kota Palembang 2017.Pusat data dan Informasi Kesehatan : Palembang. 2017 
GATS. 2011. Global Adults Tobacco Survey Indonesia Report 2011.New Delhi : WHO Regional Office For South-East Asia

Khoirudin, (2006). perbedaan kapasitas vital paru dan tekanan darah antara perokok aktif dengan perokok pasif pada siswa Madrasah Hidayatul Mubtadi'in Semarang Tahun Ajaran 2005/2006. Fakultas IImu Keolahragaan Universitas Negeri Semarang.

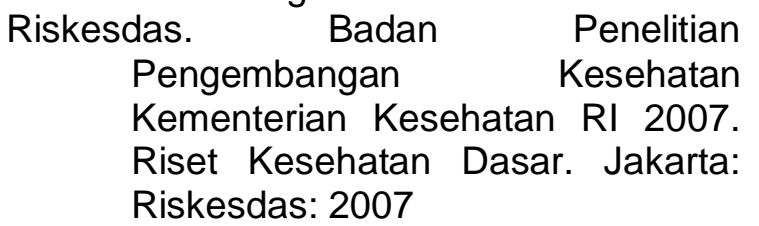
Riskesdas. Badan Penelitian Pengembangan Kesehatan Kementerian Kesehatan RI 2010. Riset Kesehatan Dasar. Jakarta: Riskesdas: 2010

Riskesdas. Badan Penelitian Pengembangan Kesehatan Kementerian KesehatanRI 2018. Riset Kesehatan Dasar. Jakarta: Riskesdas: 2018

SIRKESNAS. 2016. Survei Indikator Kesehatan Nasional.Jakarta: Badan Penelitian Pengembangan Ksehatan Kementrian Kesehatan RI.

Sudarmoko. (2015). Tetap Tersenyum Melawan Hipertensi. Yogyakarta: Atma Madia Press.

Sukmana T. (2008). Agar Terhindar Dari Rokok. Jakarta: Be Champion, Pp: 4-14.

WebMD.com, 2018, Drug Interaction Checker, Terdapat di: https://www.webmd.com/interaction -checker/default.htm [Diakses pada January 10, 2018].

WHO. 2013. About Cardiovascular diseases. World Health Organization.Geneva. Cited July 15th2014. Available from URL : http://www.who.int/cardiovascular diseases/about_cvd/en/ accessed on

Wismanto, $Y$ Bagusdan $Y$ Budi Sarwo. 2007. Strategi Penghentian Perilaku Merokok. Semarang
:Unika Soegijapranata. http://eprints.unika.ac.id/236/1/Stra hen_Prilaku_Mrokok.pdf(Diakses 27 November 2013).

World Health Organization. A global brief on hypertension: silent killer, global public health crisis. 2015. 